\title{
The Trinity of $\mathrm{Ca}^{2+}$ Sources for the Exocytotic Glutamate Release from Astrocytes
}

\author{
Reno C. Reyes and Vladimir Parpura* \\ ${ }^{1}$ Department of Neurobiology, Center for Glial Biology in Medicine, Atomic Force Microscopy \& \\ Nanotechnology Laboratories, Civitan International Research Center, Evelyn F. McKnight Brain \\ Institute, University of Alabama, Birmingham, AL 35294
}

\begin{abstract}
Astrocytes can exocytotically release the transmitter glutamate. Increased cytosolic $\mathrm{Ca}^{2+}$ concentration is necessary and sufficient in this process. The source of $\mathrm{Ca}^{2+}$ for the $\mathrm{Ca}^{2+}$-dependent exocytotic release of glutamate from astrocytes predominately comes from endoplasmic reticulum (ER) stores with contributions from both inositol 1,4,5 trisphosphate- and ryanodine/caffeinesensitive stores. An additional source of $\mathrm{Ca}^{2+}$ comes from the extracellular space via store-operated $\mathrm{Ca}^{2+}$ entry due to the depletion of ER stores. Here transient receptor potential canonical type 1 containing channels permit entry of $\mathrm{Ca}^{2+}$ to the cytosol, which can then be transported by the storespecific Ca2+-ATPase to (re)fill ER. Mitochondria can modulate cytosolic $\mathrm{Ca}^{2+}$ levels by affecting two aspects of the cytosolic $\mathrm{Ca}^{2+}$ kinetics in astrocytes. They play a role in immediate sequestration of $\mathrm{Ca}^{2+}$ during the cytosolic $\mathrm{Ca}^{2+}$ increase in stimulated astrocytes as a result of $\mathrm{Ca}^{2+}$ entry into the cytosol from ER stores and/or extracellular space. As cytosolic $\mathrm{Ca}^{2+}$ declines due to activity of pumps, such as the smooth $\mathrm{ER} \mathrm{Ca}^{2+}$-ATPase, free $\mathrm{Ca}^{2+}$ is slowly released by mitochondria into cytosol. Taken together, the trinity of $\mathrm{Ca}^{2+}$ sources, ER, extracellular space and mitochondria, can vary concentration of cytosolic $\mathrm{Ca}^{2+}$ which in turn can modulate $\mathrm{Ca}^{2+}$ - dependent vesicular glutamate release from astrocytes. An understanding of how these $\mathrm{Ca}^{2+}$ sources contribute to glutamate release in (patho)physiology of astrocytes will provide information on astrocytic functions in health and disease and may also open opportunities for medical intervention.
\end{abstract}

\section{Keywords}

astrocytes; glutamate release; exocytosis; $\mathrm{Ca}^{2+} \mathrm{ER}$ stores; SOC entry; TRPC1; mitochondria

\begin{abstract}
A developing body of evidence implicates astrocytes as active participants in multi-directional signaling in the central nervous system (CNS) [reviewed in (Haydon and Carmignoto, 2006; Theodosis et al., 2008)]. Astrocytes communicate with neurons (Nedergaard, 1994; Parpura et al., 1994), endothelial cells of the cerebrovasculature (Zonta et al., 2003; Mulligan and MacVicar, 2004), and microglia (Davalos et al., 2005). They appear to be an integral part of neural communication throughout the CNS. For example, in the hippocampus, astrocytes integrate neuronal signals (Perea and Araque, 2005), potentiate transmitter release at single synapses (Perea and Araque, 2007), enhance long-term potentiation (Pascual et al., 2005), and
\end{abstract}

Correspondence should be addressed to: Vladimir Parpura, Department of Neurobiology, 1719 6th Avenue South, CIRC 429, University of Alabama, Birmingham, AL 35294; phone: (205) 996-7369; fax: (205) 975-6320; e-mail: E-mail: vlad@uab.edu.

Publisher's Disclaimer: This is a PDF file of an unedited manuscript that has been accepted for publication. As a service to our customers we are providing this early version of the manuscript. The manuscript will undergo copyediting, typesetting, and review of the resulting proof before it is published in its final citable form. Please note that during the production process errors may be discovered which could affect the content, and all legal disclaimers that apply to the journal pertain. 
synchronize neuronal activity (Fellin et al., 2004). In the thalamus, astrocytes have been shown to drive neuronal activity as a consequence of astrocytic intrinsic $\mathrm{Ca}^{2+}$ oscillations (Parri et al., 2001). In the supraoptic nucleus of the hypothalamus, morphological plasticity of astrocytes (Hatton, 2004) leading to differential synaptic coverage by astrocytic processes can modulate the activity of the output neurons (Panatier et al., 2006).

The abundance of astrocytes and their proximity to neurons enables their communication with neurons. Early studies indicated the numerical preponderance of glial cells in the CNS. For example, in layers I and IV of the rat cerebral cortex, glial cells consisting of astrocytes and oligodendrocytes, outnumbered neurons 3 to 1 (Bass et al., 1971). As more sophisticated tools for cell counting emerged, it appears, however, that the glia to neuron ratio in human cortex is $\sim$ 1.65:1, while in rodent this ratio is about 0.3:1 (Nedergaard et al., 2003; Sherwood et al., 2006). Astrocytes occupy distinct domains within the CNS, only at the cells' peripheries do their processes overlap (Bushong et al., 2002; Ogata and Kosaka, 2002). Within their individual domains astrocytes have extensive morphological interactions with neurons. For example, in the cortex of adult mice, one astrocyte may contact 4 to 8 neurons and surround $\sim 300$ to 600 neuronal dendrites (Halassa et al., 2007). In the hippocampus, astrocytes are positioned to contact even more synapses. In adult rats, one astrocyte is estimated to contact $\sim 140,000$ synapses of CA1 pyramidal cells (Bushong et al., 2002). Classically, the intimate position of astrocytic processes around the neurons and the synapses has been solely attributed to glutamate uptake and regulation of extracellular $\mathrm{K}^{+}$by astrocytes. To provide these services, astrocytes possess excitatory amino acid transporters (EAAT's) (Huang and Bergles, 2004; Tzingounis and Wadiche, 2007; Yang and Rothstein, 2009) and $\mathrm{K}^{+}$inward rectifying (Kir) channels (Sontheimer et al., 1994; Kofuji and Newman, 2009), respectively. However, it is also at synapses where astrocytes have been shown to have modulatory effects on the activities of presynaptic and postsynaptic neurons by astrocytic ability to release a variety of transmitters using many different mechanisms [reviewed in (Malarkey and Parpura, 2009)]. This led to the concept of a functional tripartite synapse (Araque et al., 1999), a topic that has been recently reviewed elsewhere (Ni et al., 2007; Halassa and Haydon, 2009).

In this review we focus on the $\mathrm{Ca}^{2+}$ sources for the exocytotic release of the excitatory transmitter glutamate from astrocytes, which can readily occur under physiological conditions (Parpura and Haydon, 2000). We start with a historical brief on the $\mathrm{Ca}^{2+}$-dependent glutamate release from astrocytes [reviewed in detail in (Montana et al., 2004)]. We then discuss the trinity of $\mathrm{Ca}^{2+}$ sources for this release: intracellular stores, extracellular space and mitochondria. An understanding of how these $\mathrm{Ca}^{2+}$ sources contribute to the glutamate release will provide information on glial functions in heath and disease and may also introduce opportunities for medical intervention.

\section{$\mathrm{Ca}^{2+-}$ dependent glutamate release in astrocytes: a historical brief}

Astrocytes can couple their inherent intracellular $\mathrm{Ca}^{2+}$ excitability to the exocytotic release of transmitters including but not limited to glutamate (Parpura et al., 1994). Throughout this review we interchangeably use $\mathrm{Ca}^{2+}$-dependent and exocytotic attributes of glutamate release from astrocytes. Excitation-secretion coupling in astrocytes involves the molecular machinery for vesicular fusion, including the core members of the soluble N-ethyl maleimide-sensitive fusion protein attachment protein receptor (SNARE) complex, as well as proteins responsible for packaging of glutamate inside vesicles, vacuolar type proton ATPase and vesicular glutamate transporters [reviewed in (Montana et al., 2006; Malarkey and Parpura, 2008)].

Evidence for $\mathrm{Ca}^{2+}$-dependent release of glutamate from astrocytes was originally demonstrated in experiments where the application of the $\mathrm{Ca}^{2+}$ ionophore ionomycin stimulated the release of glutamate from astrocytes in the presence of external free $\mathrm{Ca}^{2+}(2.4 \mathrm{mM})$. However, this 
ionophore failed to cause glutamate release when applied to astrocytes that were equilibrated in solution with low external free $\mathrm{Ca}^{2+}(24 \mathrm{nM})$, for 40-60 minutes, thus causing the depletion of internal $\mathrm{Ca}^{2+}$ stores and preventing the $\mathrm{Ca}^{2+}$ entry from the extracellular space (Parpura et al., 1994). These data indicate that $\mathrm{Ca}^{2+}$ is sufficient and necessary to cause glutamate release from astrocytes. Indeed, depleting internal $\mathrm{Ca}^{2+}$ stores by application of thapsigargin, a blocker of the sarco-endoplasmic reticulum $\mathrm{Ca}^{2+}$-ATPase (SERCA), or buffering cytoplasmic $\mathrm{Ca}^{2+}$

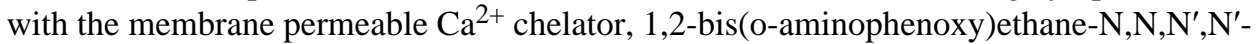
tetraacetic acid acetoxymethyl ester (BAPTA-AM), resulted in reduction of glutamate release (Araque et al., 1998a; Bezzi et al., 1998; Innocenti et al., 2000; Hua et al., 2004; Montana et al., 2004). Furthermore, alternative stimuli that directly increased astrocytic intracellular $\mathrm{Ca}^{2+}$ concentration $\left(\left[\mathrm{Ca}^{2+}\right]_{\mathrm{i}}\right.$ ), such as mechanical stimulation (Parpura et al., 1994; Araque et al., 1998a; Araque et al., 1998b; Hua et al., 2004; Montana et al., 2004), photostimulation (Parpura et al., 1994), and photolysis of $\mathrm{Ca}^{2+}$ cages (Araque et al., 1998b; Parpura and Haydon, 2000), all caused release of glutamate.

\section{The trinity of $\mathrm{Ca}^{2+}$ sources}

The source of $\mathrm{Ca}^{2+}$ for $\mathrm{Ca}^{2+}$-dependent release of glutamate from astrocytes is tripartite, from (i) internal ER stores, (ii) extracellular space and (iii) mitochondria (Figure 1).

\section{(i) Inositol 1,4,5 trisphosphate ( $\left.\mathrm{IP}_{3}\right)$ - and ryanodine/caffeine-sensitive ER stores}

The ER is the major source of intracellular $\mathrm{Ca}^{2+}$, and it appears to be the main determinant of $\mathrm{Ca}^{2+}$ excitability in astrocytes (Verkhratsky, 2006; Deitmer et al., 2008). The concentration of free $\mathrm{Ca}^{2+}$ inside the ER ([Ca $\left.{ }^{2+}\right]_{\mathrm{ER}}$ ) ranges from 100 to $800 \mu \mathrm{M}$ (Burdakov et al., 2005) while the basal concentration of this ion in cytosol $\left(\left[\mathrm{Ca}^{2+}\right]_{\mathrm{cyt}}\right)$ is $\sim 100 \mathrm{nM}$. Ca ${ }^{2+}$ can be released from the ER through $\mathrm{IP}_{3}$ receptors $\left(\mathrm{IP}_{3} \mathrm{R}\right)$ and $\mathrm{Ca}^{2+}$-induced $\mathrm{Ca}^{2+}$ release (CICR) by activation of caffeine/ryanodine sensitive receptors (RyR) (Simpson et al., 1998). These two ER receptor/ channel types may gate distinct $\mathrm{Ca}^{2+}$ stores (Golovina and Blaustein, 2000), although this notion has not been widely accepted [e.g., (Hua et al., 2004); see below]. The $\left[\mathrm{Ca}^{2+}\right]_{\mathrm{ER}}$ can affect the sensitivity of the RyRs to cytosolic $\mathrm{Ca}^{2+}$ as well as the activity of the SERCA pumps (Burdakov et al., 2005). Thus, at the level of the ER, there is regulation of $\mathrm{Ca}^{2+}$ release and entry.

The initial, but indirect indication that $\mathrm{ER}$ stores play role in $\mathrm{Ca}^{2+}$-dependent release of glutamate from astrocytes came from experiments in which the neuroligand bradykinin which caused cytosolic $\mathrm{Ca}^{2+}$ elevation in astrocytes also induced glutamate release from these glial cells (Parpura et al., 1994). Bradykinin binds to G-protein coupled plasma membrane receptors which activate the $\mathrm{IP}_{3}$ pathway, and cause release of $\mathrm{Ca}^{2+}$ from the ER (Cholewinski et al., 1988; Stephens et al., 1993). In addition to bradykinin, other ligands including ATP can induce $\mathrm{Ca}^{2+}$ release from the ER (Peuchen et al., 1996) through the $\mathrm{IP}_{3}$ pathway (Kastritsis et al., 1992). Indeed, ATP stimulation of purinergic 2 receptors caused an increase in astrocytic cytosolic $\mathrm{Ca}^{2+}$ which coincided with an increase in glutamate release from cultured astrocytes to the extracellular space (Jeremic et al., 2001). This ATP action was greatly reduced when astrocytes were pre-incubated with thapsigargin, implicating the role of ER stores in providing cytosolic $\mathrm{Ca}^{2+}$ for exocytotic glutamate release.

Hua et al. (2004) demonstrated that both $\mathrm{IP}_{3}$ - sensitive and ryanodine/caffeine-sensitive stores play a role in $\mathrm{Ca}^{2+}$-dependent mechanically-induced glutamate release from astrocytes. The $\mathrm{Ca}^{2+}$ source for this exocytotic release is predominately from internal stores, as indicated by reduction of mechanically-induced glutamate release in the presence of thapsigargin. To test whether $\mathrm{IP}_{3}$ - sensitive internal stores mediate $\mathrm{Ca}^{2+}$-dependent glutamate release from astrocytes, these cells were bathed in diphenylboric acid 2-aminoethyl ester (2-APB) solution, a cell-permeant $\mathrm{IP}_{3} \mathrm{R}$ antagonist. This agent greatly reduced exocytotic glutamate release. Next, 
the role of ryanodine/caffeine-sensitive ER stores was assessed by incubating astrocytes with ryanodine, which at concentrations used $(10 \mu \mathrm{M})$ blocked the release of $\mathrm{Ca}^{2+}$ from the ryanodine/caffeine- sensitive stores. Ryanodine also attenuated mechanically -induced glutamate release. Furthermore, the sustained presence of caffeine that depleted ryanodine/ caffeine stores, also reduced mechanically -induced glutamate release. It should be noted, however, that the functionality of ryanodine receptors in astrocytes is still debated, since the lack of their activity in astrocytes in situ had been reported (Beck et al., 2004). Nonetheless, when astrocytes in culture were pre-treated with the combination of 2-APB with ryanodine or caffeine, there was no additive effect on reduction of mechanically-induced glutamate release when compared to treatments with one pharmacological agent only. Since all pharmacological agents used in this study showed cytosolic $\mathrm{Ca}^{2+}$ changes that were in good agreement with glutamate release, these data suggested that exocytotic glutamate release requires the coactivation of both $\mathrm{IP}_{3}$ - and ryanodine/caffeine-sensitive internal $\mathrm{Ca}^{2+}$ stores and that these stores are operating jointly (Figure 1).

\section{(ii) Extracellular space}

Astrocytes utilize extracellular $\mathrm{Ca}^{2+}$ as well as $\mathrm{ER} \mathrm{Ca}^{2+}$ for exocytotic glutamate release (Figure 1). This is evidenced by the reduction of $\mathrm{Ca}^{2+}$-dependent glutamate release from astrocytes not only in the presence of thapsigargin, but also in the presence of extracellular $\mathrm{Cd}^{2+}$, a blocker of $\mathrm{Ca}^{2+}$ entry from the extracellular space (Hua et al., 2004). It should be noted that remaining glutamate release in stimulated astrocytes pre-treated with thapsigargin or $\mathrm{Cd}^{2+}$ were $\sim 30 \%$ and $55 \%$ of control, respectively, indicating that the internal stores are the predominant source of $\mathrm{Ca}^{2+}$ for exocytotic release.

$\mathrm{Ca}^{2+}$ entry across the astrocytic plasma membrane involves a variety of channels [reviewed in (Verkhratsky et al., 1998); see below]. Ultimately, the (re)filling of $\mathrm{ER} \mathrm{Ca}^{2+}$ stores requires $\mathrm{Ca}^{2+}$ entry from the extracellular space through so called store-operated $\mathrm{Ca}^{2+}$ (SOC) channels (Takemura and Putney, 1989; Golovina, 2005). Canonical transient receptor potential (TRPC) channels, which have been implicated in SOC entry, have been found in astrocytes where they play a role in the regulation of $\mathrm{Ca}^{2+}$ homeostasis (Pizzo et al., 2001; Grimaldi et al., 2003; Golovina, 2005). TRPC1 functionally contributes to $\mathrm{Ca}^{2+}$-dependent glutamate release from astrocytes. Malarkey et al. (2008) detected the presence of TRPC1 in cultured and freshlyisolated astrocytes, along with two other isoforms with which TRPC1 is known to form heteromultimeric channels, TRPC4 and TRPC5 (Strubing et al., 2001; Hofmann et al., 2002; Strubing et al., 2003). It should be noted that TRPC1 does not commonly form homomeric channels (Strubing et al., 2003). When looking at the function of these proteins, Malarkey et al. (2008) measured the extent of SOC entry in cultured astrocytes. Astrocytic internal $\mathrm{Ca}^{2+}$ stores were depleted by applying cyclopiazonic acid (CPA), which blocks SERCA and (re) filling the stores. Concomitantly, the entry of external $\mathrm{Ca}^{2+}$ was prevented by bathing the astrocytes in $\mathrm{Ca}^{2+}$ free external saline solution. This depletion of $\mathrm{Ca}^{2+}$ from internal stores led to opening of SOC channels, which was evident by the increased cytosolic $\mathrm{Ca}^{2+}$ when the bathing solution was changed to external solution containing $\mathrm{Ca}^{2+}$. This increase was pharmacologically confirmed to be due to $\mathrm{Ca}^{2+}$ entry through SOC channels using $\mathrm{La}^{3+}$, $\mathrm{Gd}^{3+}$ and MRS-1845, compounds known to inhibit SOC channels (Harper et al., 2003; Rychkov and Barritt, 2007).

In experiments using a similar SOC entry assay to the one described above, Golovina (2005) demonstrated significant reduction of SOC entry in cultured astrocytes after an antisense knockdown of the TRPC1 gene. To address whether the acute block of TRPC1 affects SOC entry, Malarkey et al. (2008) used an antibody against TRPC1 that was designed to bind to the pore forming region of TRPC1 and block the functioning of the channel (Wang et al., 1999). This antibody caused a significant decrease in the measured amount of SOC entry in astrocytes. 
Such immunological interference with TRPC 1 channels also showed that the SOC entry through TRPC1 plays a role in mechanically-induced cytosolic $\mathrm{Ca}^{2+}$ elevations and the consequent $\mathrm{Ca}^{2+}$-dependent release of glutamate from astrocytes (Figure 1). The reduction of glutamate release in astrocytes pretreated with antibody was $\sim 39 \%$ of control, thus at similar level to that seen in astrocytes treated with thapsigargin (Hua et al., 2004).

It is obvious by now that astrocytes are unlike neurons in which the predominant source of $\mathrm{Ca}^{2+}$ for exocytotic release at synaptic terminals is extracellular, mediated via $\mathrm{Ca}^{2+}$ entry though voltage-gated $\mathrm{Ca}^{2+}$ channels (VGCCs). However, VGCCs were found in astrocytes (Latour et al., 2003; Mulligan and MacVicar, 2004). Since the driving force for the for $\mathrm{Ca}^{2+}$ entry into astrocytes is similar to that in neurons with the extracellular $\mathrm{Ca}^{2+}$ concentration $\left(\left[\mathrm{Ca}^{2+}\right]_{\mathrm{ext}}\right) \sim 2 \mathrm{mM}$ being four orders greater than $\left[\mathrm{Ca}^{2+}\right]_{\mathrm{cyt}}$, the inability to detect the activity of VGCCs in hippocampal astrocytes in situ may implicate the low level of expression and/or low plasma membrane density of VGCCs (Carmignoto et al., 1998). Although the role of VGCCs in glutamate release from astrocytes is unclear at present, there is some evidence in support of their involvement in this process. Using freshly prepared slices from ventrobasal thalamus, Parri et al. (2001) showed that astrocytes in situ display intrinsic $\left[\mathrm{Ca}^{2+}\right]_{\mathrm{cyt}}$ oscillations. These oscillations were not driven by neuronal activity since they could not be blocked by tetrodotoxin. Astrocytes in situ displaying spontaneous $\left[\mathrm{Ca}^{2+}\right]_{\text {cyt }}$ oscillations could cause N-methy-D-aspartate (NMDA) receptor-mediated neuronal excitability. Thus astrocytic spontaneous $\left[\mathrm{Ca}^{2+}\right]_{\text {cyt }}$ oscillations lead to glutamate release from these glial cells. Although oscillations where driven by $\mathrm{Ca}^{2+}$ released from intracellular stores since they were blocked by SERCA blockers thapsigargin and CPA, they were also inhibited to the similar extent by the dihydropyridine (DHP) antagonist nifedipine (Parri et al., 2001). This demonstrates the involvement of DHP-sensitive L-type VGCCs in astrocytic cytosolic $\mathrm{Ca}^{2+}$ dynamics. Conversely, the DHP agonist BayK8644 increased the number of astrocytes displaying cytosolic $\mathrm{Ca}^{2+}$ oscillations (Parri and Crunelli, 2003). Additionally, increasing the driving force for $\mathrm{Ca}^{2+}$ entry by increasing $\left[\mathrm{Ca}^{2+}\right]_{\text {ext }}$ (to $5 \mathrm{mM}$ ) increased the number of spontaneously active astrocytes and the number of cytosolic $\mathrm{Ca}^{2+}$ transient increases displayed by individual astrocytes (Parri and Crunelli, 2003). Even though the effect of VGCC manipulations on glutamate release from astrocytes of ventrobasal thalamus has not been assessed, it is tempting to speculate that these channels may be a conduit for $\mathrm{Ca}^{2+}$ supply for glutamate release from astrocytes (Figure 1).

Ionotropic neurotransmitter receptors represent an additional entry of $\mathrm{Ca}^{2+}$ in astrocytes [reviewed in (Verkhratsky, 2009)]. The role of ligand-gated ionotropic receptors in exocytotic glutamate release from astrocytes is provisional at the moment, however. Given that astrocytes can respond to glutamatergic and cholinergic synaptic inputs by increases in $\left[\mathrm{Ca}^{2+}\right]_{\mathrm{cyt}}$ (Dani et al., 1992; Porter and McCarthy, 1996; Araque et al., 2002), we briefly discuss nicotinic acetylcholine receptors, and glutamatergic, $\alpha$-amino-3-hydroxy-5-methyl-4-

isoxazolepropionic acid (AMPA) and NMDA, receptors on astrocytes. Recent findings indicate that astrocytes express functional nicotinic acetylcholine receptors, particularly those with $\alpha 7$ subunits (Sharma and Vijayaraghavan, 2001). Activation of these receptors on astrocytes can lead to $\left[\mathrm{Ca}^{2+}\right]_{\text {cyt }}$ increases, which require CICR and the activation of ryanodine/ caffeine-sensitve internal stores. The dominant glutamatergic ionotropic receptors on astrocytes are AMPA receptors, which are found in astroglial cells throughout the brain (Verkhratsky and Steinhauser, 2000; Seifert and Steinhauser, 2001; Aguirre et al., 2004). Astrocytes in hippocampus express GluR2 subunit and thus display low $\mathrm{Ca}^{2+}$ permeability through their AMPA channels (Seifert et al., 2003). Hence, a challenge of hippocampal astrocytes with AMPA does not cause glutamate release (Bezzi et al., 1998). However, some types of astrocytes do not express the GluR2 subunit. For example, Bergmann glia, an astrocytic cell found in the cerebellum, expresses AMPA receptors that are $\mathrm{Ca}^{2+}$ permeable. These cells ensheathe parallel fiber-Purkinje cell synapses (Grosche et al., 1999). There, electrical 
stimulation of parallel fibers to release glutamate caused rapid and transient $\left[\mathrm{Ca}^{2+}\right]_{\text {cyt }}$ elevations within Bergmann glial processes (Grosche et al., 1999). Functional astrocytic NMDA receptors were only recently detected in cortical astrocytes (Lalo et al., 2006). Interestingly, astrocytic NMDA channels grossly differ from neuronal since they do not show a $\mathrm{Mg}^{2+}$ block at resting membrane potentials (around $-80 \mathrm{mV}$ ). Whether activation of these, and other ionotropic receptors expressed by astrocytes leading to increases in $\left[\mathrm{Ca}^{2+}\right]_{\text {cyt }}$ would also lead to $\mathrm{Ca}^{2+}$-dependent glutamate release is unknown at the moment.

Another $\mathrm{Ca}^{2+}$ entry point that needs further investigation is at plasma membrane $\mathrm{Na}^{+} / \mathrm{Ca}^{2+}$ exchangers. While they are known to extrude $\mathrm{Ca}^{2+}$ during high cytosolic loads of this cation in conjuction with the plasma membrane $\mathrm{Ca}^{2+}$-ATPase (PMCA), several reports have shown that the exchanger works in reverse to increase $\left[\mathrm{Ca}^{2+}\right]_{\text {cyt }}$ (Goldman et al., 1994; Benz et al., 2004; Rojas et al., 2007). Hence, release of homeocysteic acid (HCA) from cultured astrocytes can be $\mathrm{Ca}^{2+}$-dependent and mediated by activation of glutamate receptors (Benz et al., 2004). It appears that the agonist stimulation led to intracellular $\mathrm{Na}^{+}$load through ionotropic glutamate receptors, which then activated $\mathrm{Na}^{+} / \mathrm{Ca}^{2+}$ exchangers to extrude $\mathrm{Na}^{+}$from astrocytes while importing $\mathrm{Ca}^{2+}$ to the cytosol, resulting in a rise of $\left[\mathrm{Ca}^{2+}\right]_{\text {cyt }}$. This cascade of events was inferred from the observation that agonist-induced HCA release was blocked in the presence of benzamil, a Na$/ \mathrm{Ca}^{2+}$ exchanger blocker. While some have argued that the reverse mode of this exchanger only occurs at pathophysiological conditions, it is worth investigating what this exchanger contributes to physiological $\mathrm{Ca}^{2+}$ entry and consequential exocytoctic glutamate release from astrocytes.

\section{(ii) Mitochondria}

In astrocytes, mitochondria form filamentous reticula, and are in perpetual fusion and fission as they are in other cell types (Westermann, 2002). Mitochondria congregate perinuclearly, but can be located at the cell periphery including processes (Collins et al., 2002). To achieve translocation, mitochondria travel on microtubules and actin filaments. While the actin cytoskeleton dictates the distribution of mitochondria, it appears that the intermediate filament vimentin may be involved as well (Tang et al., 2008). Interestingly, in neurons mitochondria display activity-dependent motility at the synapses (Li et al., 2004; Chang et al., 2006; Mironov, 2006).

Mitochondria are efficient $\mathrm{Ca}^{2+}$ sinks during periods when rapid increases in $\left[\mathrm{Ca}^{2+}\right]_{\text {cyt }}$ occur in a cell. They possess a mitochondrial $\mathrm{Ca}^{2+}$ uniporter (MCU) that can transport $\mathrm{Ca}^{2+}$ into the mitochondrial matrix powered by a negative membrane potential (between $-140 \mathrm{mV}$ and -180 $\mathrm{mV}$ ) across the inner mitochondrial membrane generated by the electron transport chain. In contrast to the SERCA and PMCA which have higher affinities for $\mathrm{Ca}^{2+}$ than the MCU, $\mathrm{Ca}^{2+}$ is taken up by MCU only at $\left[\mathrm{Ca}^{2+}\right]_{\text {cyt }}$ greater than $\sim 0.5 \mu \mathrm{M}$ (Miyata et al., 1991; Simpson and Russell, 1998) and dominates $\mathrm{Ca}^{2+}$ transport at $\sim 10 \mu \mathrm{M}$ and above (Alonso et al., 2006). While such high concentrations are normally not reached in the bulk cytosol, they exist at high $\mathrm{Ca}^{2+}$ loci known as microdomains (Schneggenburger and Neher, 2005; Oheim et al., 2006). Indeed, Rizzuto et al. (1998) showed that mitochondria are juxtaposed to $\mathrm{IP}_{3}$ channels of the ER and are exposed to higher concentrations of $\mathrm{Ca}^{2+}$ than what would exist at the bulk cytosol. Indeed, $\mathrm{Ca}^{2+}$ released from the $\mathrm{IP}_{3}$-sensitve intracellular stores in mucosal mast cells caused local $\left[\mathrm{Ca}^{2+}\right]_{\text {cyt }}$ increases of over $16 \mu \mathrm{M}$ (Csordas et al., 2006). Thus, it seems reasonable to assume that similar localized $\left[\mathrm{Ca}^{2+}\right]_{\mathrm{i}}$ increases would occur in astrocytes.

It should be noted that as conditions in a cell are not homogenous i.e. ion concentration, mitochondrial $\mathrm{Ca}^{2+}$ handling is not homogenous either. In T lymphocytes, subsets of mitochondria modulates the entry of $\mathrm{Ca}^{2+}$ through the SOC channels by translocation (Hoth et al., 1997; Quintana et al., 2007). This is a likely function of some mitochondria in astrocytes as well. Kolikova et al. (2006) demonstrated using total internal reflection fluorescence 
microscopy that at least a subset of mitochondria become trapped near the plasma membrane when cultured astrocytes are challenged with glutamate or ATP. Indeed, numerous studies of various cells types report that different subsets of mitochondria take up $\mathrm{Ca}^{2+}$ depending whether stimulated cells released $\mathrm{ER} \mathrm{Ca}^{2+}$ or whether they allowed $\mathrm{Ca}^{2+}$ entry from the extracellular space (Simpson and Russell, 1996; Collins et al., 2001).

As sinks to trap free $\mathrm{Ca}^{2+}$ released from the ER, mitochondria are positioned to affect transient $\mathrm{Ca}^{2+}$ increases required for vesicle fusion, and exocytosis in secretory cells. Reyes and Parpura (2008) demonstrated that mitochondria can modulate $\left[\mathrm{Ca}^{2+}\right]_{\text {cyt }}$ and glutamate release in cortical astrocytes challenged with mechanical stimuli. Taking a pharmacological approach, we showed in parallel experiments that blocking the MCU with ruthenium 360 (Ru60) increased the cytosolic $\mathrm{Ca}^{2+}$ accumulation, and glutamate release in cortical astrocytes. In contrast to Ru360 treatment, decreasing mitochondrial $\mathrm{Ca}^{2+}$ efflux by blocking the mitochondrial $\mathrm{Na}^{+}$/ $\mathrm{Ca}^{2+}$ exchanger with CGP37157, or increasing mitochondrial $\mathrm{Ca}^{2+}$ load by inhibiting formation of the mitochondrial permeability transition pore with cyclosporin $\mathrm{A}$, decreased cytosolic $\mathrm{Ca}^{2+}$ accumulation, and glutamate release in cortical astrocytes. Hence, these data suggest that the transient increase in $\left[\mathrm{Ca}^{2+}\right]_{\mathrm{cyt}}$ is correlative to the amount of glutamate released in cortical astrocytes, and that mitochondria have the capacity to modulate the degree of this release. Taken together, astrocytic mitochondria may be active modulators of $\mathrm{Ca}^{2+}$-dependent glutamate release from astrocytes. They could act as temporary holding compartments of excess $\mathrm{Ca}^{2+}$ at the fine astrocytic processes surrounding the tripartite synapse, in a similar manner as has previously been shown in neuronal terminals at the neuromuscular junction (Tang and Zucker, 1997).

\section{Concluding Remarks}

The purpose of this review was to summarize the $\mathrm{Ca}^{2+}$ sources for exocytotic glutamate release from astrocytes. There are three major $\mathrm{Ca}^{2+}$ sources that contribute to this process: (i) the predominant source from internal ER stores, (ii) the SOC entry from the extracellular space and (iii) mitochondria, as outlined in Figure 1. There are several issues that remain to be resolved. As indicated earlier, the activation of ionotropic receptors expressed by astrocytes can lead to increases in $\left[\mathrm{Ca}^{2+}\right]_{\mathrm{cyt}}$. Whether this excitation is coupled to the $\mathrm{Ca}^{2+}$-dependent exocytotic glutamate release from these cells awaits further experimentation. Furthermore, it will be necessary to determine whether the same $\mathrm{Ca}^{2+}$ sources operate under physiological and pathological conditions or whether there are specific $\mathrm{Ca}^{2+}$ sources operating under particular conditions. For example, acute oxidative stress in astrocytes causes influx of extracellular $\mathrm{Ca}^{2+}$ through L-type VGCCs (Bond and Greenfield, 2007). Whether this $\mathrm{Ca}^{2+}$ source plays a role in exocytotic glutamate release from astrocytes and whether such release occur in various neurodegenerative diseases causatively linked to oxidative stress remains to be assessed. Alternatively, all possible $\mathrm{Ca}^{2+}$ sources could operate together in astrocytes at all times, but each contributing a different portion to the total amount of glutamate being released. It appears that addressing these questions in cell culture systems depends on application of sufficient human time and effort, since many of the specific reagents and methods, some of which are described earlier, for teasing apart the contributions from individual $\mathrm{Ca}^{2+}$ sources have already been developed. Although such an approach would require a labor intensive effort of information collection and analysis, it is a pre-requisite before taking experiments out of culture dishes and rigorously testing hypotheses on freely-moving animals and humans.

\section{Acknowledgements}

We thank Randy F. Stout, Jr. for comments on previous versions of this manuscript. This work is supported by a grant from the National Institute of Mental Health (MH 069791 to VP) and the National Institute of Heath Neuroscience Training Program in Neurobiology of Cognition and Cognitive Disorders at University of Alabama, Birmingham (to $\mathrm{RCR})$. 


\section{References}

Aguirre AA, Chittajallu R, Belachew S, Gallo V. NG2-expressing cells in the subventricular zone are type C-like cells and contribute to interneuron generation in the postnatal hippocampus. J Cell Biol 2004;165:575-589. [PubMed: 15159421]

Alonso MT, Villalobos C, Chamero P, Alvarez J, Garcia-Sancho J. Calcium microdomains in mitochondria and nucleus. Cell Calcium 2006;40:513-525. [PubMed: 17067669]

Araque A, Parpura V, Sanzgiri RP, Haydon PG. Glutamate-dependent astrocyte modulation of synaptic transmission between cultured hippocampal neurons. Eur J Neurosci 1998a;10:2129-2142. [PubMed: 9753099]

Araque A, Sanzgiri RP, Parpura V, Haydon PG. Calcium elevation in astrocytes causes an NMDA receptor-dependent increase in the frequency of miniature synaptic currents in cultured hippocampal neurons. J Neurosci 1998b;18:6822-6829. [PubMed: 9712653]

Araque A, Parpura V, Sanzgiri RP, Haydon PG. Tripartite synapses: glia, the unacknowledged partner. Trends Neurosci 1999;22:208-215. [PubMed: 10322493]

Araque A, Martin ED, Perea G, Arellano JI, Buno W. Synaptically released acetylcholine evokes Ca2+ elevations in astrocytes in hippocampal slices. J Neurosci 2002;22:2443-2450. [PubMed: 11923408]

Bass NH, Hess HH, Pope A, Thalheimer C. Quantitative cytoarchitectonic distribution of neurons, glia, and DNa in rat cerebral cortex. J Comp Neurol 1971;143:481-490. [PubMed: 4945394]

Beck A, Nieden RZ, Schneider HP, Deitmer JW. Calcium release from intracellular stores in rodent astrocytes and neurons in situ. Cell Calcium 2004;35:47-58. [PubMed: 14670371]

Benz B, Grima G, Do KQ. Glutamate-induced homocysteic acid release from astrocytes: possible implication in glia-neuron signaling. Neuroscience 2004;124:377-386. [PubMed: 14980387]

Bezzi P, Carmignoto G, Pasti L, Vesce S, Rossi D, Rizzini BL, Pozzan T, Volterra A. Prostaglandins stimulate calcium-dependent glutamate release in astrocytes. Nature 1998;391:281-285. [PubMed: 9440691]

Bond CE, Greenfield SA. Multiple cascade effects of oxidative stress on astroglia. Glia 2007;55:13481361. [PubMed: 17654703]

Burdakov D, Petersen OH, Verkhratsky A. Intraluminal calcium as a primary regulator of endoplasmic reticulum function. Cell Calcium 2005;38:303-310. [PubMed: 16076486]

Bushong EA, Martone ME, Jones YZ, Ellisman MH. Protoplasmic astrocytes in CA1 stratum radiatum occupy separate anatomical domains. J Neurosci 2002;22:183-192. [PubMed: 11756501]

Carmignoto G, Pasti L, Pozzan T. On the role of voltage-dependent calcium channels in calcium signaling of astrocytes in situ. J Neurosci 1998;18:4637-4645. [PubMed: 9614238]

Chang DT, Honick AS, Reynolds IJ. Mitochondrial trafficking to synapses in cultured primary cortical neurons. J Neurosci 2006;26:7035-7045. [PubMed: 16807333]

Cholewinski AJ, Hanley MR, Wilkin GP. A phosphoinositide-linked peptide response in astrocytes: evidence for regional heterogeneity. Neurochem Res 1988;13:389-394. [PubMed: 2839790]

Collins TJ, Lipp P, Berridge MJ, Bootman MD. Mitochondrial Ca(2+) uptake depends on the spatial and temporal profile of cytosolic $\mathrm{Ca}(2+)$ signals. J Biol Chem 2001;276:26411-26420. [PubMed: $11333261]$

Collins TJ, Berridge MJ, Lipp P, Bootman MD. Mitochondria are morphologically and functionally heterogeneous within cells. Embo J 2002;21:1616-1627. [PubMed: 11927546]

Csordas G, Renken C, Varnai P, Walter L, Weaver D, Buttle KF, Balla T, Mannella CA, Hajnoczky G. Structural and functional features and significance of the physical linkage between ER and mitochondria. J Cell Biol 2006;174:915-921. [PubMed: 16982799]

Dani JW, Chernjavsky A, Smith SJ. Neuronal activity triggers calcium waves in hippocampal astrocyte networks. Neuron 1992;8:429-440. [PubMed: 1347996]

Davalos D, Grutzendler J, Yang G, Kim JV, Zuo Y, Jung S, Littman DR, Dustin ML, Gan WB. ATP mediates rapid microglial response to local brain injury in vivo. Nat Neurosci 2005;8:752-758. [PubMed: 15895084]

Deitmer, JW.; Singaravelu, K.; Lohr, C. Calcium ion signaling in astrocytes. In: Parpura, V.; Haydon, PG., editors. Astrocytes in (patho)physiology of the Nervous System. Boston, MA: Springer; 2008. 
Fellin T, Pascual O, Gobbo S, Pozzan T, Haydon PG, Carmignoto G. Neuronal synchrony mediated by astrocytic glutamate through activation of extrasynaptic NMDA receptors. Neuron 2004;43:729743. [PubMed: 15339653]

Goldman WF, Yarowsky PJ, Juhaszova M, Krueger BK, Blaustein MP. Sodium/calcium exchange in rat cortical astrocytes. J Neurosci 1994;14:5834-5843. [PubMed: 7523629]

Golovina VA. Visualization of localized store-operated calcium entry in mouse astrocytes. Close proximity to the endoplasmic reticulum. J Physiol 2005;564:737-749. [PubMed: 15731184]

Golovina VA, Blaustein MP. Unloading and refilling of two classes of spatially resolved endoplasmic reticulum $\mathrm{Ca}(2+)$ stores in astrocytes. Glia 2000;31:15-28. [PubMed: 10816603]

Grimaldi M, Maratos M, Verma A. Transient receptor potential channel activation causes a novel form of [Ca2+]I oscillations and is not involved in capacitative $\mathrm{Ca} 2+$ entry in glial cells. J Neurosci 2003;23:4737-4745. [PubMed: 12805313]

Grosche J, Matyash V, Moller T, Verkhratsky A, Reichenbach A, Kettenmann H. Microdomains for neuron-glia interaction: parallel fiber signaling to Bergmann glial cells. Nat Neurosci 1999;2:139_ 143. [PubMed: 10195197]

Halassa, MM.; Haydon, PG. The tripartite synapse. In: Parpura, V.; Haydon, PG., editors. Astrocytes in (patho)physiology of the nervous system. Boston, MA: Springer; 2009. In Press

Halassa MM, Fellin T, Takano H, Dong JH, Haydon PG. Synaptic islands defined by the territory of a single astrocyte. J Neurosci 2007;27:6473-6477. [PubMed: 17567808]

Harper JL, Camerini-Otero CS, Li AH, Kim SA, Jacobson KA, Daly JW. Dihydropyridines as inhibitors of capacitative calcium entry in leukemic HL-60 cells. Biochem Pharmacol 2003;65:329-338. [PubMed: 12527326]

Hatton GI. Dynamic neuronal-glial interactions: an overview 20 years later. Peptides 2004;25:403-411. [PubMed: 15134863]

Haydon PG, Carmignoto G. Astrocyte control of synaptic transmission and neurovascular coupling. Physiol Rev 2006;86:1009-1031. [PubMed: 16816144]

Hofmann T, Schaefer M, Schultz G, Gudermann T. Subunit composition of mammalian transient receptor potential channels in living cells. Proc Natl Acad Sci U S A 2002;99:7461-7466. [PubMed: 12032305]

Hoth M, Fanger CM, Lewis RS. Mitochondrial regulation of store-operated calcium signaling in T lymphocytes. J Cell Biol 1997;137:633-648. [PubMed: 9151670]

Hua X, Malarkey EB, Sunjara V, Rosenwald SE, Li WH, Parpura V. Ca2+-dependent glutamate release involves two classes of endoplasmic reticulum Ca2+ stores in astrocytes. J Neurosci Res 2004;76:8697. [PubMed: 15048932]

Huang YH, Bergles DE. Glutamate transporters bring competition to the synapse. Curr Opin Neurobiol 2004;14:346-352. [PubMed: 15194115]

Innocenti B, Parpura V, Haydon PG. Imaging extracellular waves of glutamate during calcium signaling in cultured astrocytes. J Neurosci 2000;20:1800-1808. [PubMed: 10684881]

Jeremic A, Jeftinija K, Stevanovic J, Glavaski A, Jeftinija S. ATP stimulates calcium-dependent glutamate release from cultured astrocytes. J Neurochem 2001;77:664-675. [PubMed: 11299329]

Kastritsis CH, Salm AK, McCarthy K. Stimulation of the P2Y purinergic receptor on type 1 astroglia results in inositol phosphate formation and calcium mobilization. J Neurochem 1992;58:1277-1284. [PubMed: 1548464]

Kofuji, P.; Newman, EA. Regulation of potassium by glial cells in the central nervous system. In: Parpura, V.; Haydon, PG., editors. Astrocytes in (patho)physiology of the nervous system. Boston, MA: Springer; 2009. In Press

Kolikova J, Afzalov R, Giniatullina A, Surin A, Giniatullin R, Khiroug L. Calcium-dependent trapping of mitochondria near plasma membrane in stimulated astrocytes. Brain Cell Biol 2006;35:75-86. [PubMed: 17940914]

Lalo U, Pankratov Y, Kirchhoff F, North RA, Verkhratsky A. NMDA receptors mediate neuron-to-glia signaling in mouse cortical astrocytes. J Neurosci 2006;26:2673-2683. [PubMed: 16525046]

Latour I, Hamid J, Beedle AM, Zamponi GW, Macvicar BA. Expression of voltage-gated Ca2+ channel subtypes in cultured astrocytes. Glia 2003;41:347-353. [PubMed: 12555202] 
Li Z, Okamoto K, Hayashi Y, Sheng M. The importance of dendritic mitochondria in the morphogenesis and plasticity of spines and synapses. Cell 2004;119:873-887. [PubMed: 15607982]

Malarkey EB, Parpura V. Mechanisms of glutamate release from astrocytes. Neurochem Int 2008;52:142-154. [PubMed: 17669556]

Malarkey, EB.; Parpura, V. Mechanisms of transmitter release from astrocytes. In: Parpura, V.; Haydon, PG., editors. Astrocytes in (patho)physiology of the nervous system. Boston, MA: Springer; 2009. p. 301-350.

Malarkey EB, Ni Y, Parpura V. Ca2+ entry through TRPC1 channels contributes to intracellular Ca2+ dynamics and consequent glutamate release from rat astrocytes. Glia. 2008

Mironov SL. Spontaneous and evoked neuronal activities regulate movements of single neuronal mitochondria. Synapse 2006;59:403-411. [PubMed: 16485263]

Miyata H, Silverman HS, Sollott SJ, Lakatta EG, Stern MD, Hansford RG. Measurement of mitochondrial free Ca2+ concentration in living single rat cardiac myocytes. Am J Physiol 1991;261:H1123-1134. [PubMed: 1928394]

Montana V, Ni Y, Sunjara V, Hua X, Parpura V. Vesicular glutamate transporter-dependent glutamate release from astrocytes. J Neurosci 2004;24:2633-2642. [PubMed: 15028755]

Montana V, Malarkey EB, Verderio C, Matteoli M, Parpura V. Vesicular transmitter release from astrocytes. Glia 2006;54:700-715. [PubMed: 17006898]

Mulligan SJ, MacVicar BA. Calcium transients in astrocyte endfeet cause cerebrovascular constrictions. Nature 2004;431:195-199. [PubMed: 15356633]

Nedergaard M. Direct signaling from astrocytes to neurons in cultures of mammalian brain cells. Science 1994;263:1768-1771. [PubMed: 8134839]

Nedergaard M, Ransom B, Goldman SA. New roles for astrocytes: redefining the functional architecture of the brain. Trends Neurosci 2003;26:523-530. [PubMed: 14522144]

Ni Y, Malarkey EB, Parpura V. Vesicular release of glutamate mediates bidirectional signaling between astrocytes and neurons. J Neurochem 2007;103:1273-1284. [PubMed: 17727631]

Ogata K, Kosaka T. Structural and quantitative analysis of astrocytes in the mouse hippocampus. Neuroscience 2002;113:221-233. [PubMed: 12123700]

Oheim M, Kirchhoff F, Stuhmer W. Calcium microdomains in regulated exocytosis. Cell Calcium 2006;40:423-439. [PubMed: 17067670]

Panatier A, Theodosis DT, Mothet JP, Touquet B, Pollegioni L, Poulain DA, Oliet SH. Glia-derived Dserine controls NMDA receptor activity and synaptic memory. Cell 2006;125:775-784. [PubMed: 16713567]

Parpura V, Haydon PG. Physiological astrocytic calcium levels stimulate glutamate release to modulate adjacent neurons. Proc Natl Acad Sci U S A 2000;97:8629-8634. [PubMed: 10900020]

Parpura V, Basarsky TA, Liu F, Jeftinija K, Jeftinija S, Haydon PG. Glutamate-mediated astrocyte-neuron signalling. Nature 1994;369:744-747. [PubMed: 7911978]

Parri HR, Crunelli V. The role of $\mathrm{Ca} 2+$ in the generation of spontaneous astrocytic $\mathrm{Ca} 2+$ oscillations. Neuroscience 2003;120:979-992. [PubMed: 12927204]

Parri HR, Gould TM, Crunelli V. Spontaneous astrocytic Ca2+ oscillations in situ drive NMDARmediated neuronal excitation. Nat Neurosci 2001;4:803-812. [PubMed: 11477426]

Pascual O, Casper KB, Kubera C, Zhang J, Revilla-Sanchez R, Sul JY, Takano H, Moss SJ, McCarthy $\mathrm{K}$, Haydon PG. Astrocytic purinergic signaling coordinates synaptic networks. Science 2005;310:113-116. [PubMed: 16210541]

Perea G, Araque A. Properties of synaptically evoked astrocyte calcium signal reveal synaptic information processing by astrocytes. J Neurosci 2005;25:2192-2203. [PubMed: 15745945]

Perea G, Araque A. Astrocytes potentiate transmitter release at single hippocampal synapses. Science 2007;317:1083-1086. [PubMed: 17717185]

Peuchen S, Clark JB, Duchen MR. Mechanisms of intracellular calcium regulation in adult astrocytes. Neuroscience 1996;71:871-883. [PubMed: 8867055]

Pizzo P, Burgo A, Pozzan T, Fasolato C. Role of capacitative calcium entry on glutamate-induced calcium influx in type-I rat cortical astrocytes. J Neurochem 2001;79:98-109. [PubMed: 11595762] 
Porter JT, McCarthy KD. Hippocampal astrocytes in situ respond to glutamate released from synaptic terminals. J Neurosci 1996;16:5073-5081. [PubMed: 8756437]

Quintana A, Schwindling C, Wenning AS, Becherer U, Rettig J, Schwarz EC, Hoth M. T cell activation requires mitochondrial translocation to the immunological synapse. Proc Natl Acad Sci U S A 2007;104:14418-14423. [PubMed: 17726106]

Reyes RC, Parpura V. Mitochondria modulate Ca2+-dependent glutamate release from rat cortical astrocytes. J Neurosci 2008;28:9682-9691. [PubMed: 18815254]

Rizzuto R, Pinton P, Carrington W, Fay FS, Fogarty KE, Lifshitz LM, Tuft RA, Pozzan T. Close contacts with the endoplasmic reticulum as determinants of mitochondrial $\mathrm{Ca} 2+$ responses. Science 1998;280:1763-1766. [PubMed: 9624056]

Rojas H, Colina C, Ramos M, Benaim G, Jaffe EH, Caputo C, DiPolo R. Na+ entry via glutamate transporter activates the reverse $\mathrm{Na}+\mathrm{Ca} 2+$ exchange and triggers $\mathrm{Ca}(\mathrm{i}) 2+$-induced $\mathrm{Ca} 2+$ release in rat cerebellar Type-1 astrocytes. J Neurochem 2007;100:1188-1202. [PubMed: 17316398]

Rychkov G, Barritt GJ. TRPC1 Ca(2+)-permeable channels in animal cells. Handb Exp Pharmacol 2007:23-52. [PubMed: 17217049]

Schneggenburger R, Neher E. Presynaptic calcium and control of vesicle fusion. Curr Opin Neurobiol 2005;15:266-274. [PubMed: 15919191]

Seifert G, Steinhauser C. Ionotropic glutamate receptors in astrocytes. Prog Brain Res 2001;132:287299. [PubMed: 11544996]

Seifert G, Weber M, Schramm J, Steinhauser C. Changes in splice variant expression and subunit assembly of AMPA receptors during maturation of hippocampal astrocytes. Mol Cell Neurosci 2003;22:248-258. [PubMed: 12676534]

Sharma G, Vijayaraghavan S. Nicotinic cholinergic signaling in hippocampal astrocytes involves calcium-induced calcium release from intracellular stores. Proc Natl Acad Sci U S A 2001;98:41484153. [PubMed: 11259680]

Sherwood CC, Stimpson CD, Raghanti MA, Wildman DE, Uddin M, Grossman LI, Goodman M, Redmond JC, Bonar CJ, Erwin JM, Hof PR. Evolution of increased glia-neuron ratios in the human frontal cortex. Proc Natl Acad Sci U S A 2006;103:13606-13611. [PubMed: 16938869]

Simpson PB, Russell JT. Mitochondria support inositol 1,4,5-trisphosphate-mediated Ca2+ waves in cultured oligodendrocytes. J Biol Chem 1996;271:33493-33501. [PubMed: 8969213]

Simpson PB, Russell JT. Role of mitochondrial Ca2+ regulation in neuronal and glial cell signalling. Brain Res Brain Res Rev 1998;26:72-81. [PubMed: 9600625]

Simpson PB, Holtzclaw LA, Langley DB, Russell JT. Characterization of ryanodine receptors in oligodendrocytes, type 2 astrocytes, and O-2A progenitors. J Neurosci Res 1998;52:468-482. [PubMed: 9589392]

Sontheimer H, Fernandez-Marques E, Ullrich N, Pappas CA, Waxman SG. Astrocyte Na+ channels are required for maintenance of $\mathrm{Na}+\mathrm{K}(+)$-ATPase activity. J Neurosci 1994;14:2464-2475. [PubMed: 8182422]

Stephens GJ, Cholewinski AJ, Wilkin GP, Djamgoz MB. Calcium-mobilizing and electrophysiological effects of bradykinin on cortical astrocyte subtypes in culture. Glia 1993;9:269-279. [PubMed: 8112820]

Strubing C, Krapivinsky G, Krapivinsky L, Clapham DE. TRPC1 and TRPC5 form a novel cation channel in mammalian brain. Neuron 2001;29:645-655. [PubMed: 11301024]

Strubing C, Krapivinsky G, Krapivinsky L, Clapham DE. Formation of novel TRPC channels by complex subunit interactions in embryonic brain. J Biol Chem 2003;278:39014-39019. [PubMed: 12857742]

Takemura H, Putney JW Jr. Capacitative calcium entry in parotid acinar cells. Biochem J 1989;258:409412. [PubMed: 2650680]

Tang HL, Lung HL, Wu KC, Le AH, Tang HM, Fung MC. Vimentin supports mitochondrial morphology and organization. Biochem J 2008;410:141-146. [PubMed: 17983357]

Tang Y, Zucker RS. Mitochondrial involvement in post-tetanic potentiation of synaptic transmission. Neuron 1997;18:483-491. [PubMed: 9115741]

Theodosis DT, Poulain DA, Oliet SH. Activity-dependent structural and functional plasticity of astrocyteneuron interactions. Physiol Rev 2008;88:983-1008. [PubMed: 18626065] 
Tzingounis AV, Wadiche JI. Glutamate transporters: confining runaway excitation by shaping synaptic transmission. Nat Rev Neurosci 2007;8:935-947. [PubMed: 17987031]

Verkhratsky A. Glial calcium signaling in physiology and pathophysiology. Acta Pharmacol Sin 2006;27:773-780. [PubMed: 16787559]

Verkhratsky, A. Neurotransmitter receptors in astrocytes. In: Parpura, V.; Haydon, PG., editors. Astrocytes in (patho)physiology of the nervous system. Boston, MA: Springer; 2009. In Press

Verkhratsky A, Steinhauser C. Ion channels in glial cells. Brain Res Brain Res Rev 2000;32:380-412. [PubMed: 10760549]

Verkhratsky A, Orkand RK, Kettenmann H. Glial calcium: homeostasis and signaling function. Physiol Rev 1998;78:99-141. [PubMed: 9457170]

Wang W, O’Connell B, Dykeman R, Sakai T, Delporte C, Swaim W, Zhu X, Birnbaumer L, Ambudkar IS. Cloning of Trp1beta isoform from rat brain: immunodetection and localization of the endogenous Trp1 protein. Am J Physiol 1999;276:C969-979. [PubMed: 10199829]

Westermann B. Merging mitochondria matters: cellular role and molecular machinery of mitochondrial fusion. EMBO Rep 2002;3:527-531. [PubMed: 12052774]

Yang, Y.; Rothstein, JD. Specialized neurotransmitter transporters in astrocytes. In: Parpura, V.; Haydon, PG., editors. Astrocytes in (patho)physiology of the nervous system. Boston, MA: Springer; 2009. In Press

Zonta M, Angulo MC, Gobbo S, Rosengarten B, Hossmann KA, Pozzan T, Carmignoto G. Neuron-toastrocyte signaling is central to the dynamic control of brain microcirculation. Nat Neurosci 2003;6:43-50. [PubMed: 12469126] 


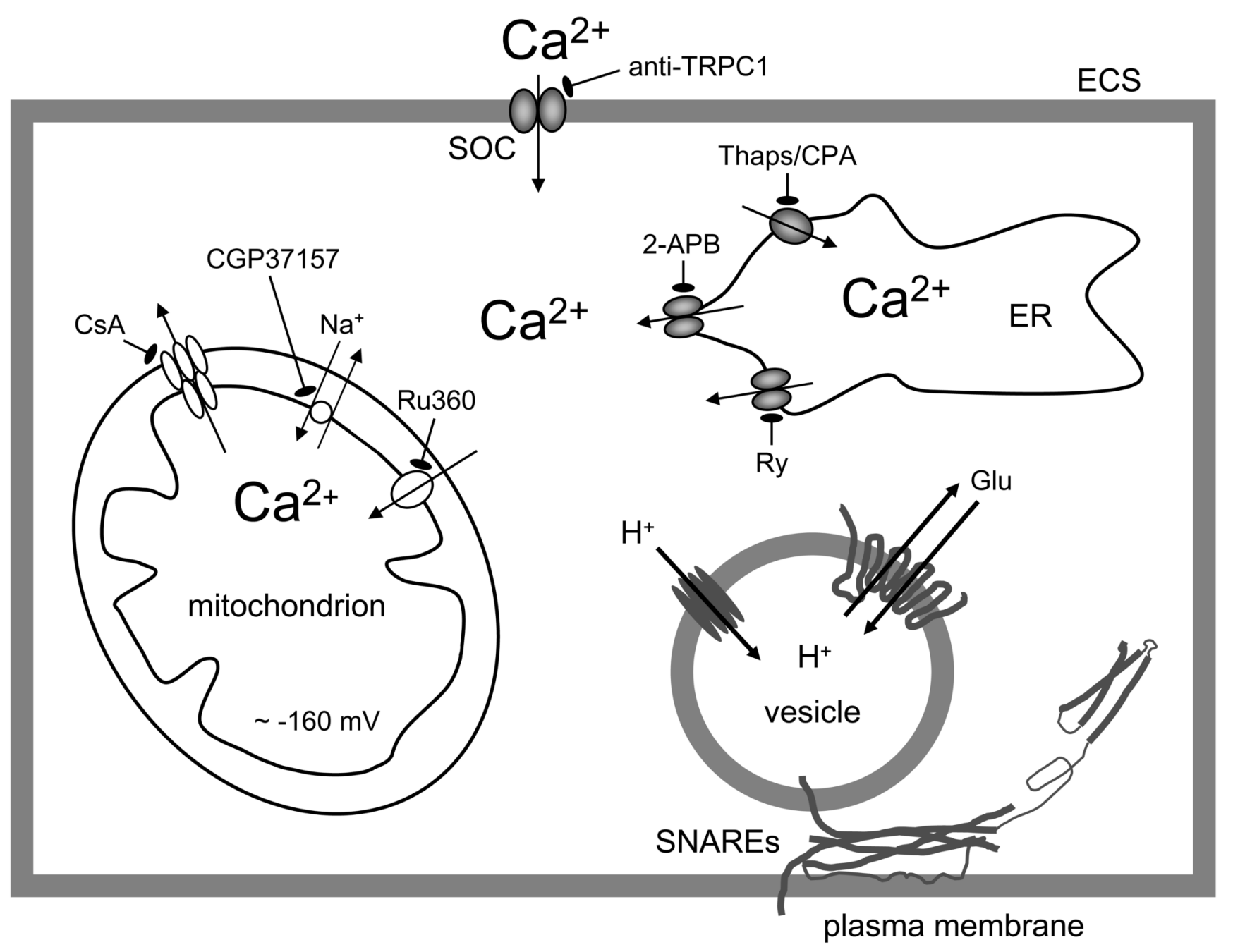

Figure 1.

Tripartite $\mathrm{Ca}^{2+}$ cyt handling in $\mathrm{Ca}^{2+}$ - dependent vesicular glutamate release from astrocytes. A drawing of sources of $\mathrm{Ca}^{2+}$ for $\left[\mathrm{Ca}^{2+}\right]_{\text {cyt }}$ increase. $\left[\mathrm{Ca}^{2+}\right]_{\text {cyt }}$ can be affected by the endoplasmic reticulum (ER), store-operated $\mathrm{Ca}^{2+}$ (SOC) entry and mitochondria. $\mathrm{Ca}^{2+}$ cyt accumulation could be caused by the entry of $\mathrm{Ca}^{2+}$ from the internal stores of the ER that possess $\mathrm{IP}_{3}$ and ryanodine receptors. The pre-incubation of astrocytes with ryanodine $(\mathrm{Ry})$ can block $\mathrm{Ca}^{2+}$ release from ryanodine/caffeine-sensitve ER stores, while diphenylboric acid 2-aminoethyl ester (2-APB), an $\mathrm{IP}_{3} \mathrm{R}$ antagonist, reduces $\mathrm{Ca}^{2+}$ release from an $\mathrm{IP}_{3}$-senistive stores.

Thapsigargin (Thaps) and cyclopiazonic acid (CPA), blockers of store specific $\mathrm{Ca}^{2+}$-ATPase, prevent filling of these stores by $\mathrm{Ca}^{2+}$ and, thus, deplete stores of this ion. Ultimately, the (re) filling of $\mathrm{ER} \mathrm{Ca}^{2+}$ stores requires $\mathrm{Ca}^{2+}$ entry from the extracellular space (ECS) through SOC channels, in particular those containing canonical type 1 transient receptor potential (TRPC1) protein. A specific TRPC1 antibody blocks TRPC1 containing SOC channels and reduces $\mathrm{Ca}^{2+}$ entry to the cytosol. A negative membrane potential (about $-160 \mathrm{mV}$ ) exists across the inner mitochondrial membrane. Mitochondrial $\mathrm{Ca}^{2+}$ uptake is mediated by the uniporter as the electropotential gradient drives $\mathrm{Ca}^{2+}$ into the matrix. Ru360 blocks $\mathrm{Ca}^{2+}$ influx through the uniporter. Free $\mathrm{Ca}^{2+}$ exits the mitochondrial matrix through the $\mathrm{Na}^{+} / \mathrm{Ca}^{2+}$ exchanger, and this process can be blocked by CGP37157. $\mathrm{Ca}^{2+}$ accumulation in mitochondria is increased by cyclosporin A (CsA) via preventing formation of the mitochondrial permeability transition 
pore, which releases $\mathrm{Ca}^{2+}$ and other components of the mitochondrial matrix at high $\mathrm{Ca}^{2+}$ loads. Increase of $\mathrm{Ca}^{2+}$ cyt is sufficient and necessary to cause vesicular fusions and release of glutamate, which requires action by proteins of the ternary SNARE complex and their associated proteins (not shown). Additionally, vesicles possess the vacuolar type $\mathrm{H}^{+}$-ATPase which creates the proton gradient used by vesicular glutamate transporters to fill these organelles with glutamate (Glu). Drawing is not to scale. 